\title{
Sward quality affected by different grazing pressures on dairy systems
}

\author{
MARIA ROSA MOSQUERA-LOSADA, ANTONIO GONZALEZ-RODRÍGUEZ, AND ANTONIO RIGUEIRO- \\ RODRIGUEZ
}

Authors are professor and assistant professor Crop Production Department, Escuela Politécnica Superior, University Santiago de Compostela, 27002-Lugo, Spain and Researcher Milk Production, the Agrarian Research Centre of Mabegondo. 15080. A Coruña, Spain.

Abstract

The objective of the experiment was to examine the effects of different stocking densities $\left(3.7,4.6\right.$, and 5.5 cows ha $\left.{ }^{-1}\right)$ on tiller density, botanical composition, and chemical (crude protein [CP], acid detergent fiber [ADF], Ca, P, K, and Mg) quality of pasture and the seasonal (before flowering [spring], after flowering [summer], and autumn) distribution of these parameters. Percentages of sown [perennial ryegrass (Lolium perenne $\mathrm{L}$. cv 'Brigantia') and white clover (Trifolium repens L. cv 'Huia')] and volunteer species were not significantly affected by stocking density, although as stocking density increased, tiller density also increased. This effect was more pronounced for volunteer species than sown species. Density was significantly higher before flowering than after flowering or autumn. Stocking density affected the chemical quality of herbage with ADF, CP, P, K, and Mg higher at high stocking density. The $\mathrm{Ca} / \mathrm{P}$ relationship was lower at high stocking density, but the $\mathrm{K} /(\mathrm{Ca}+\mathrm{Mg})$ relationship was not significantly affected by stocking density. Chemical quality of the pasture was higher before flowering than after flowering or autumn. The $\mathrm{Ca} / \mathrm{P}$ ratio exceeded the upper limit recommended for dairy cows, but no osteomalacia was found in the present experiment. Low values of the $\mathrm{K} /(\mathrm{Ca}+\mathrm{Mg})$ ratio were found in the spring. Therefore, on these pasture types it is advisable to use concentrates high in Mg or Mg supplements in the spring in order to avoid hypomagnesemia.

Key Words: Lolium, stocking rate, Trifolium

Pasture production and its seasonal distribution are important variables which determine animal production. However, it is important to know other characteristics relating to the sward such as density (number of tillers per square meter) and botanical composition, which can affect pasture production and herbage intake. Density and botanical composition are usually affected by management decisions, such as stocking rate or density (Curll and Wilkins 1985, Baker and Leaver 1986).

Forage intake is dependent on the availability of forage, on the chemical and physical composition of the forage, and on the nutritional requirements of the animal (Minson 1982). Therefore,

Research was funded in part by Agricultural, Food and Fisheries National Ministry and by Agricultural and Fisheries Galician Regional Ministry.

Authors thank Dra. Teresa Brea, Dra. Pilar Castro, Dr. Juan Piñeiro and Dr. Jesús Moreno, J. Valenzuela for assistance in field and statistical analyses.

Manuscript accepted 17 Feb. 2000.
Resumen

El objetivo de este experimento fue evaluar el efecto de diferentes cargas ganaderas $\left(3.7,4.6\right.$ y 5.5 vacas ha $\left.^{-1}\right)$ sobre la densidad, composición botánica y calidad química (proteína bruta (PB), fibra ácido detergente (FAD), Ca, P, K y Mg) del pasto y la distribución estacional (antes de la floración [primavera], después de la floración [verano], y otoño) de estos parámetros. Los porcentajes de las especies sembradas [raigrás inglés (Lolium perenne L. var "Brigantia") y trébol (Trifolium repens $\mathrm{L}$. var 'Huia")] y espontáneas no se vieron significativamente afectados por la carga ganadera, sin embargo a medida que la carga ganadera aumentó, la densidad del pasto se incrementó. Este efecto fue más pronunciado para las especies espontáneas que para las sembradas.

La densidad fue significativamente mayor antes de la floración que después de la floración o en otoño. La carga ganadera afectó a la calidad química de la hierba, resultando los contenidos en FAD, PB, P, K, y Mg mayores con las cargas más altas. La relación $\mathrm{Ca} / \mathrm{P}$ fue menor en las cargas altas, sin embargo la relación $\mathrm{K} /(\mathrm{Ca}+\mathrm{Mg})$ no fue significativamente afectada por este parámetro. La calidad química del pasto fue mayor antes de la floración que después de este período o en otoño. A pesar de que la relación $\mathrm{Ca} / \mathbf{P}$ fue mayor que el límite superior recomendado para vacas de leche, no se encontraron casos de osteomalacia en este experimento. Se encontraron valores bajos de la relación $\mathrm{K} /(\mathrm{Ca}+\mathrm{Mg})$ en la primavera. Por lo tanto en este tipo de pastos es recomendable utilizar concentrados ricos en Mg o complementados con Mg en primavera para evitar problemas de hipomagnesemia.

herbage quality is an important factor which affects animal production, and knowledge about its seasonal distribution is necessary to make management decisions such as use of supplements or calving dates.

Chemical analysis of pasture is an indirect method of determining availability of an element to an animal. It is important to know the mineral contents of pastures which are grazed because there are some important differences with ungrazed pastures (Frame and Hunt 1971). Mineral content, that exceeds or falls short of the optimal requirements of grazing animals can cause health and production problems. Milk fever or hypocalcaemia (Pickard 1986, Grace 1983a, Minson 1990) is a pathology related to a deficit of calcium in dairy diet and can lead to occasional bone disorders. Hypomagnesaemia or grass tentany is produced when magnesium is not given in adequate proportion in the diet and causes mainly a reduction on milk production and fertility of 
cows (Pickard 1986, Minson 1990, Grace 1983a). Deficiency of potassium is not usual as pasture has substantial percentage of this element, but if it is in excess then it will cause problems with magnesium absorption and therefore precipitate hypomagnesaemia (Minson 1990).

Protein content and ADF of pasture are related to intake (Mott 1983, Minson 1982) and are affected by climatic conditions (Munro and Walters 1985, Metson and Saunders 1978b, Roberts 1987, Stehr and Kirchgessner, 1976).

Our objective was to determine the effect of differing stocking densities on botanical composition, density, and chemical characteristics (ADF, CP, and mineral content) of dairy system pastures in Spain, as well as the seasonal distribution of these parameters.

\section{Materials and Methods}

The experiment was carried out in Mabegondo (Galicia region) $\left(43^{\circ} 15^{\prime} \mathrm{N}\right.$, $\left.8^{\circ} 18^{\prime} \mathrm{W}\right)$ during 3 years of a dairy systems study. In the study, 3 treatments were established: Treatment A was pasture only and Treatment B was a pasture plus corn+rye (Zea mays L.+ Secale cereale L.) for silage. Both Treatments A and B had an overall stocking rate of 2.5 cows ha ${ }^{-1}$. Treatment $\mathrm{C}$ was also a pasture plus corn+rye silage system, but the overall stocking rate was 3 cows ha ${ }^{-1}$. Due to the different overall stocking rates and land area allocated for grazing vs. corn+rye or forage-based silage production, the effective stocking densities for the pasture component of each treatment differed during the year and are shown in Table 1 . The average stocking density for the grazing component of the treatments was 3.7, 4.6, and 5.5 cows ha' ${ }^{-1}$ for $\mathrm{A}, \mathrm{B}$, and $\mathrm{C}$, respec-
Table 1. Stocking rates $\left(\operatorname{cow} \mathrm{ha}^{-1}\right)$ for each treatment and period pre-flowering (pre), post flowering (post) and autumn for 1989, 1990, and 1991.

\begin{tabular}{llccc}
\hline \hline & & \multicolumn{3}{c}{ Treatment } \\
& & A & B & C \\
\hline \multirow{2}{*}{1989} & & $-\ldots-\left(\right.$ cows ha $\left.^{-1}\right)$ & ---- \\
& pre & 4.93 & 5.00 & 5.55 \\
& post & 4.32 & 4.58 & 5.74 \\
& autumn & 2.47 & 4.17 & 5.65 \\
1990 & pre & 4.93 & 5.00 & 5.55 \\
& post & 2.87 & 4.56 & 5.72 \\
& autumn & 2.73 & 4.72 & 5.65 \\
1991 & pre & 4.93 & 5.00 & 5.55 \\
& post & 2.78 & 3.92 & 5.09 \\
& autumn & 3.57 & 4.69 & 5.47 \\
\hline
\end{tabular}

tively. The effect of the 3 stocking rates on animal production and on pasture production had been evaluated by Mosquera and González (1998, 1999).

The total area for the systems studied was 8.1, 8.0, and 6.7 ha for treatments A, B, and $\mathrm{C}$, respectively. Each treatment was grazed with Friesian breed dairy cows with live weights of approximately $500 \mathrm{~kg}$.

For all treatments, the pasture area was sown with a mixture of $22 \mathrm{~kg} \mathrm{ha}^{-1}$ perennial ryegrass cv. Brigantia and $4 \mathrm{~kg} \mathrm{ha}^{-1}$ white clover cv. Huia. On average, the swards were 5 years old and they contained about $60 \%$ sown species (mostly perennial ryegrass) at the start of the experiment.

\section{Grazing management}

Cows were rotationally grazed across paddocks from March until the forage supply was limited by drought. The average number of grazing days per paddock was around 1.9 and the average regrowth period was 25 days. Areas reserved for grass silage production were all cut before flowering (15 May) and then integrated into the grazing cycle if necessary in the autumn. During the summer, cows were usually fed silage until autumn growth provided enough herbage to graze. Cows resumed grazing in the autumn after sufficient herbage mass had accumulated after the summer drought and continued grazing until herbage production was limited by cold temperatures.

While grazing, cows were offered a similar daily herbage allowance (around $15 \mathrm{~kg}$ cow $^{-1}$ day $^{-1}$ ). This was achieved by changing regrowth period and grazing days.

\section{Measurements}

In each paddock, 5 random samples of available herbage were taken just before grazing $(0.33 \times 0.33 \mathrm{~m}$ area cut to $2.5 \mathrm{~cm}$ above ground level). Samples were taken every time that cows were moved into a paddock in each rotation. Samples were stored at $4^{\circ} \mathrm{C}$ until processing (never more than 5 days). Samples were dried $\left(70^{\circ} \mathrm{C}\right.$ for 24 hours) and weighed. Acid detergent fiber was determined by the method of Goering and Van Soest (1970). A microKjeldahl digestion technique, modified auto-analyzer, was used to determine simultaneously total $\mathrm{N}(\%)$ and $\mathrm{P}(\%)$ concentration (Castro et al., 1990). Calcium $(\%), \mathrm{K}(\%$,$) and \mathrm{Mg}(\%)$ were determined by atomic absorption spectrophotometry by using a Perkin-Elmer 460 spectrophotometer. The relationships $\mathrm{Ca} / \mathrm{P}(\%)$ and $\mathrm{K} /(\mathrm{Ca}+\mathrm{Mg})(\mathrm{meq} / \mathrm{meq})$ were calculated.

To determine botanical composition, in 1990 and 1991, a $100 \mathrm{~g}$ subsample of fresh herbage was collected from each paddock just before grazing by cutting five, $1 \mathrm{~m}^{2}$ areas to $2.5 \mathrm{~cm}$ above ground level. Subsamples of $100 \mathrm{~g}$ were taken at random and species were hand-separated, dried $\left(70^{\circ} \mathrm{C}\right.$ for 24 hours) and weighed individually for estimating composition based on dry weight. Tiller density was determined in 1991 by taking forty, $5-\mathrm{cm}$ diameter cores from each grass paddock just before grazing to measure tiller population densi-

Table 2. Percentage of sown Lolium perenne $\mathbf{L}$. and Trifolium sp., dead matter (dead) and volunteer species in spring (before flowering), summer (after flowering) and autumn in 1990 and 1991 in each treatment.

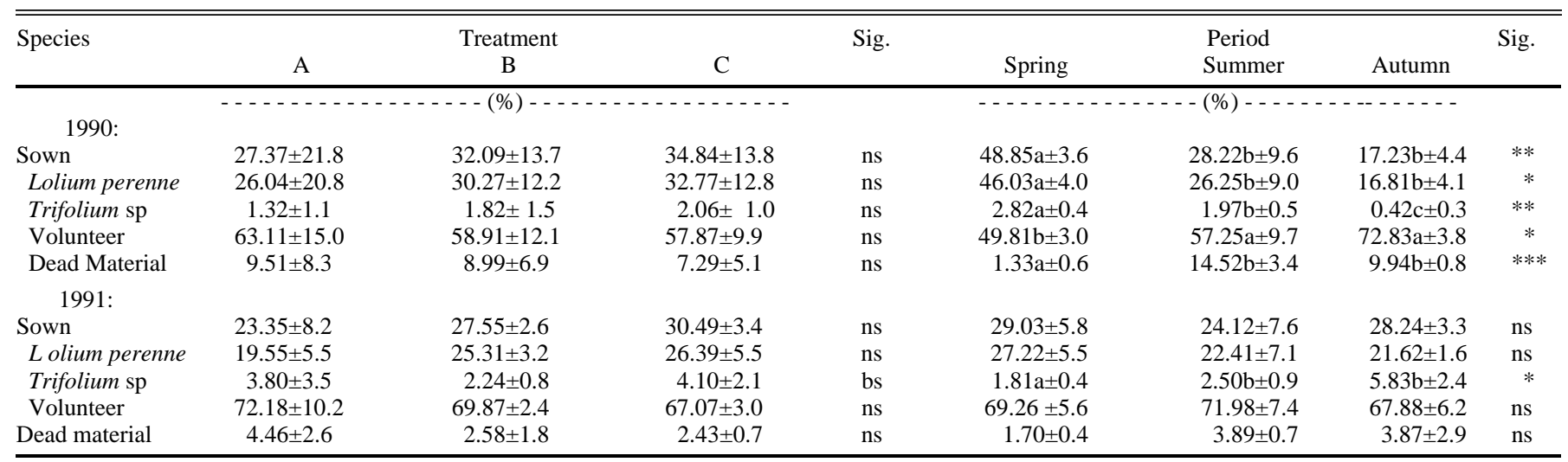



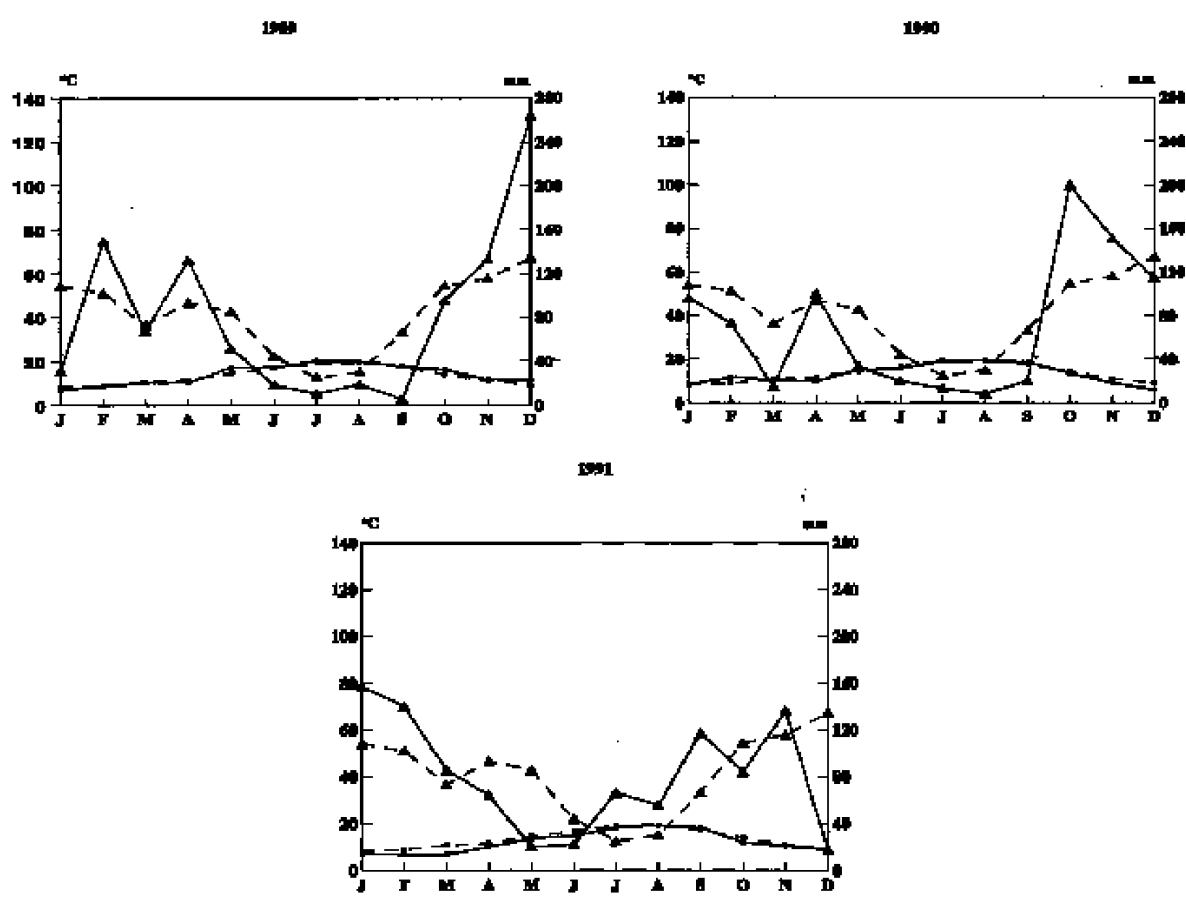

Fig. 1. Monthly rainfall $(\mathrm{mm})$ and average temperatures $\left({ }^{\circ} \mathrm{C}\right)$ for each studied year (continuous line and monthly rainfall mean of the last 20 years (1978-1998) and average temperature of the last 12 years (1986-1998) (discontinuous line). ty in each treatment. Visual estimations of dead matter and bare ground were made on each core as were tillers (every shoot and root was one tiller).

The treatment and period effect on botanical composition, tiller density, ADF, $\mathrm{CP}$, and mineral content of pasture were statistically analyzed with a two-way ANOVA. Treatment was considered as random factor and period as fixed factor as described in Little and Hills (1987) and Stockdale and King (1980). Three periods were established: before and after flowering (date of flowering is considered to be on 10 May) and autumn (starting on 10

Table 3. Sward density of different species in each treatment during 1991 (tillers $\mathbf{m}^{-2}$ )

\begin{tabular}{lcccc}
\hline \hline Species & $\mathrm{A}$ & Treatment & & Sig. \\
& $8198 \mathrm{a} \pm 1329$ & $13735 \mathrm{~b} \pm 7086$ & $16974 \mathrm{~b} \pm 11677$ & $*$ \\
Total & & & & \\
Sown: & $1755 \pm 441$ & $2433 \pm 1437$ & $2221 \pm 1159$ & $\mathrm{~ns}$ \\
Lolium perenne & $180 \pm 00$ & $1210 \pm 300$ & $766 \pm 680$ & $\mathrm{~ns}$ \\
Trifolium repens & $1955 \pm 484$ & $3643 \pm 2379$ & $2977 \pm 495$ & $\mathrm{~ns}$ \\
$\quad$ Total & $944 \pm 196$ & $996 \pm 530$ & $1277 \pm 785$ & $\mathrm{~ns}$ \\
Volunteer: & $2016 \pm 1602$ & $2124 \pm 1375$ & $2079 \pm 1452$ & $\mathrm{~ns}$ \\
$\quad$ Plantago lanceolata & $2968 \pm 878$ & $2989 \pm 545$ & $2402 \pm 1046$ & $\mathrm{~ns}$ \\
$\quad$ Holcus lanatus & $204 \pm 142$ & $203 \pm 251$ & $153 \pm 21$ & $\mathrm{~ns}$ \\
Agristus tebyus & $62 \pm 21$ & $200 \pm 40$ & $4088 \pm 6851$ & $\mathrm{~ns}$ \\
Dactylis glomerata & $465 \pm 388$ & $2674 \pm 3696$ & $1277 \pm 1404$ & $\mathrm{~ns}$ \\
Bellis perennis & $24 \pm 10$ & $131 \mathrm{~b} \pm 143$ & $1877 \pm 3242$ & $\mathrm{~ns}$ \\
Poa sp & $6242 \mathrm{a} \pm 846$ & $10091 \mathrm{~b} \pm 4728$ & $13997 \mathrm{~b} \pm 11500$ & $*$ \\
Geranium molle & $8.68 \pm 2.48$ & $3.21 \pm 6.66$ & $8.68 \pm 4.96$ & $\mathrm{~ns}$ \\
$\quad$ Total & $49 \pm 7.27$ & $55 \pm 21.6$ & $38 \pm 3.83$ & $\mathrm{~ns}$ \\
Dead matter $(\%)$ & & & &
\end{tabular}

ns:not significant; $*$ p $<0.05$
October). Means were separated by using L.S.D. test.

\section{Results}

\section{Climatic conditions}

Monthly rainfall and average temperatures for each year are presented in Figure 1. Herbage growth was usually restricted by dry conditions from July to October. In 1991, there was a dry period between May and June and an unusually wet summer (mainly July and August).

\section{Botanical composition}

Percentages of volunteer and sown species in each treatment and period are presented in Table 2. The percentages of sown and volunteer species were not significantly affected by the stocking density, but there was a tendency towards a higher percentage of sown species at the 2 higher stocking densities in 1990 and 1991.

In 1990, the percentage of volunteer species was higher in the summer and autumn than in spring, and the amount of dead material was lower in the spring. However, no differences were found for these parameters in 1991. White clover content was lower in autumn in 1990, compared to autumn 1991. In that year white clover content was higher in autumn than the other seasons. These results could be explained by the wet summer in 1991, which permitted the recovery of white clover plants along whith a lesser amount of dead tissue. Perennial ryegrass was significantly lower in summer and autumn in 1990 but did not vary due to season in 1991.

Tiller density is shown in Table 3. Increased stocking density increased tiller density of the sward. Total tiller density of Treatment $\mathrm{C}$ was double that of Treatment A. The effect of stocking density was more pronounced for volunteer than sown species.

Of the volunteer species, Agrostis ten nuis Sibth., Poa pratensis L., Holcus lana tus L., and Plantago lanceolata L. comprised about 67,63 , and $41 \%$ of total volunteer species in Treatments A, B, and C, respectively. Density of these individual species was not affected by the treatment. Increased plant density at the higher stocking density was due to the increased presence of Bellis perennis L. and Geranium molle L., which represented 30 and $12 \%$, respectively, of the volunteer species in Treatment $\mathrm{C}$. These species were present at only low numbers in the other treatments.

The density per grazing period is shown in Table 4. Densities of both volunteer and sown species were generally higher before flowering than for the other 2 periods although this varied among species.

Numbers of tillers $\mathrm{m}^{-2}$ of perennial ryegrass, white clover, $H$. lanatus, and $P$. pratensis were lower in autumn and summer than in spring. However, P. lanceola t $a$ had a higher percentage of tillers in autumn than in the summer or spring.

Species percentages obtained by weighing differed from that found by counting the number of tillers. Based on tiller numbers, the total volunteer species percentage was higher $(82 \%)$ at the high stocking density (Treatment C) than in Treatments A $(76 \%)$ or B $(73 \%)$. However based on 
2a)

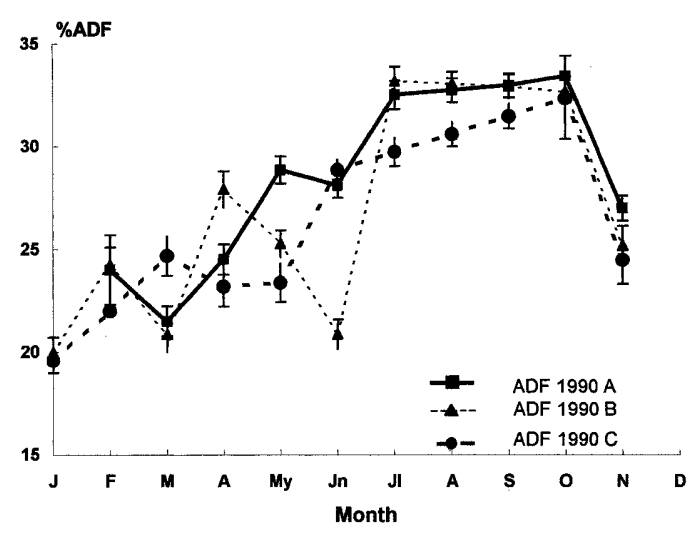

2b)

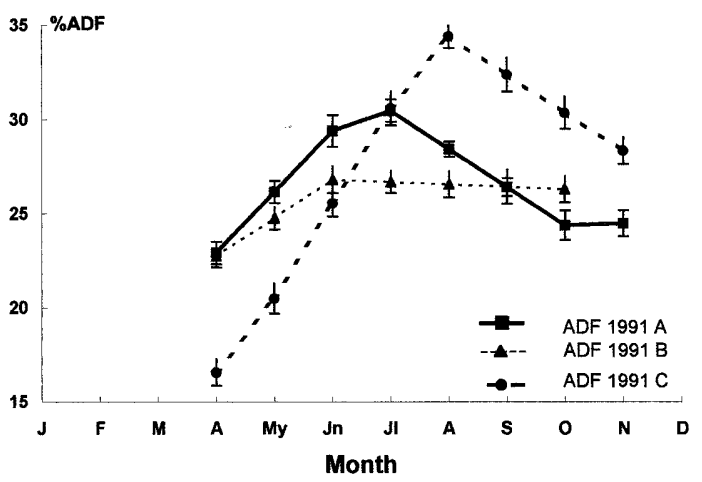

Fig. 2. Seasonal distribution of ADF for the treatments A, B, and C, in 1990 and 1991.

weight, percentage of volunteer species was lower in Treatment C $(59 \%)$ than either Treatment A $(73 \%)$ or B $(71 \%)$. This was because, although more numerous, the prostrate growth habit of the volunteer species made very little contribution to herbage mass.

\section{Protein, ADF, and mineral composition} of pasture

Two year average for sward CP, ADF, and mineral concentration and ratios for the three stocking density treatments and pre-flowering, post-flowering, and autumn periods are shown in Table 5. Acid detergent fiber was not affected by the increase of stocking density and averaged $26 \%$. Seasonal variation in ADF for 1990 and 1991 for each stocking density is presented in Figure $2 \mathrm{a}$ and $2 \mathrm{~b}$. Information from 1989 was omitted because it was very similar to 1990 . Both years, ADF was lowest in the spring before flowering and highest in the summer.

Crude protein (Table 5) concentration was lowest at the lowest stocking density, Treatment A. But, because forage availability was 68 and $211 \mathrm{~kg} \mathrm{ha}^{-1}$ more in 1990 and 1991, respectively, on treatment A than on treatments B and C, the kilograms of protein offered to cows were sim- ilar for all 3 treatments $(244.14,246.02$, and $247.30 \mathrm{~kg} \mathrm{ha}^{-1}$ for Treatments A, B, and $C$, respectively). Seasonal variation in $\mathrm{CP}$ concentration was similar for all treatments (Fig. 3a and 3b), starting off high in the spring, declining in the summer with a minimum around August, and increased again in the autumn. Average CP concen-

Table 4. Sward density (tillers $\mathrm{m}^{-2}$ ) in spring (before flowering), summer (after flowering) and autumn in 1991.

\begin{tabular}{|c|c|c|c|c|}
\hline \multirow[t]{2}{*}{ Species } & \multicolumn{4}{|c|}{ Species } \\
\hline & Spring & Summer & $\mathrm{C}$ & Sig. \\
\hline & \multicolumn{4}{|c|}{----------------------(Tillers m-2 ${ }^{-2}$--------------------- } \\
\hline Total & $2058 \mathrm{a} \pm 10485$ & $10067 \mathrm{~b} \pm 1673$ & $8254 b \pm 1297$ & $* *$ \\
\hline \multicolumn{5}{|l|}{ Sown: } \\
\hline Lolium perenne & $2907 a \pm 771$ & $2502 a \pm 542$ & $1010 b \pm 242$ & $*$ \\
\hline Trifolium repens & $1046 \pm 1321$ & $283 \pm 194$ & $827 \pm 686$ & $\mathrm{~ns}$ \\
\hline Total & $3954 a \pm 2036$ & $2785 \mathrm{ab} \pm 730$ & $183 b \pm 508$ & ns \\
\hline \multicolumn{5}{|l|}{ Volunteer: } \\
\hline Plantago lanceolata & $923 \mathrm{ab} \pm 110$ & $651 \mathrm{a} \pm 159$ & $1595 b \pm 509$ & $*$ \\
\hline Holcus lanatus & $3207 a \pm 122$ & $2678 b \pm 146$ & $434 c \pm 226$ & $* * *$ \\
\hline Dactylis glomerata & $340 \pm 164$ & $123 \pm 24$ & $96 \pm 72$ & ns \\
\hline Agrostis sp & $1659 \pm 753$ & $2801 \pm 782$ & $3011 \pm 180$ & $\mathrm{~ns}$ \\
\hline Bellis sp & $4075 \pm 6862$ & $119 \pm 47$ & $156 \pm 96$ & ns \\
\hline Poa $\mathrm{sp}$ & $3567 a \pm 3085$ & $573 b \pm 192$ & $275 b \pm 187$ & $*$ \\
\hline Geranium molle & $1918 \pm 3207$ & $103 \pm 160$ & $10 \pm 10$ & $\mathrm{~ns}$ \\
\hline Total & $16631 \mathrm{a} \pm 10122$ & $7281 b \pm 979$ & $6417 \mathrm{~b} \pm 866$ & $*$ \\
\hline Dead matter $(\%)$ & $13.33 a \pm 2.42$ & $12.15 \mathrm{a} \pm 5.34$ & $5.07 \mathrm{~b} \pm 1.26$ & * \\
\hline Bare soil $\quad(\%)$ & $53.67 \pm 23.0$ & $44.51 \pm 3.91$ & $44.42 \pm 11.21$ & ns \\
\hline
\end{tabular}


3a)

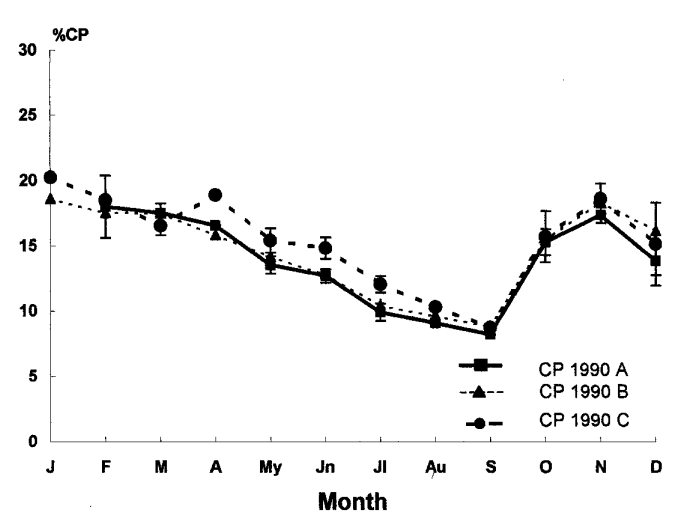

$3 b$

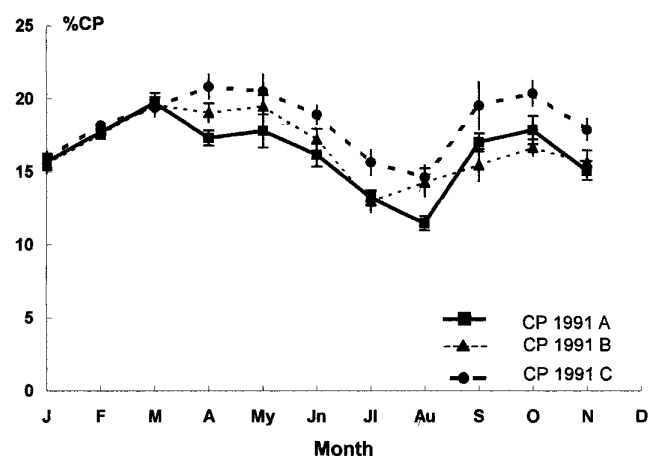

Fig. 3. Seasonal distribution of crude protein $(\mathrm{CP})$ for the treatments $A, B$, and $C$, in 1990 and 1991. 4a)

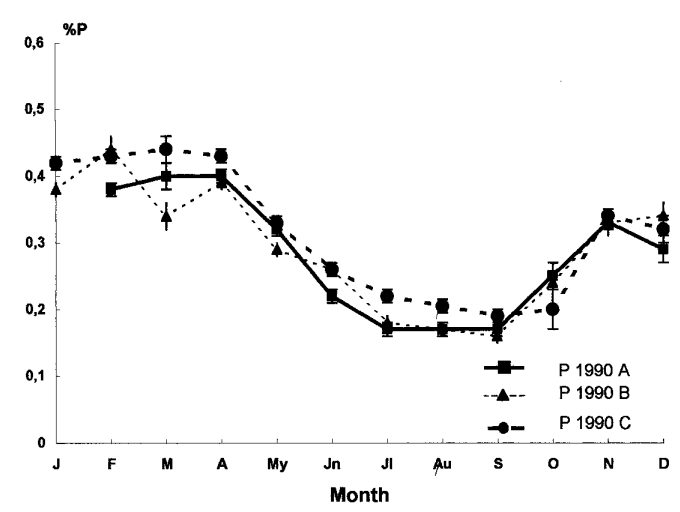

4b)

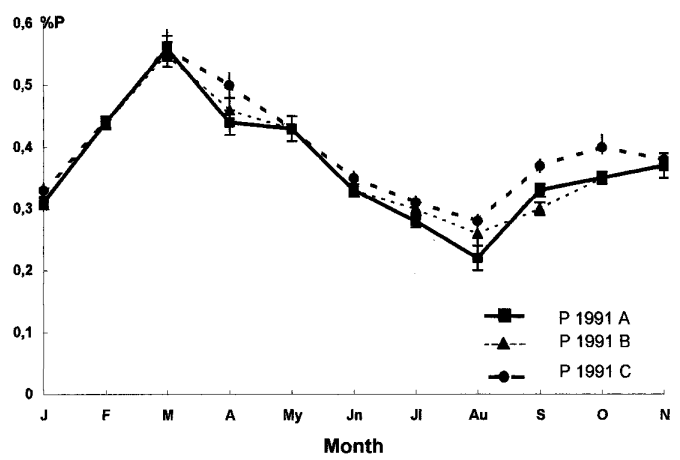

Fig. 4. Seasonal distribution of $P$ for the treatments $A, B$, and $C$, in 1990 and 1991. high in the spring and decreased in the summer and autumn. Patterns in seasonal variation in tiller density depend on species present (Hume and Lucas 1987, Garwood 1969, Takasaki et al. 1989). The majority of the species present in our study had their highest tiller density in spring (L. perenne, $T$. repens, $H$. lanatus, $D$. glomerata, $B$. perenne, $P$. annua and $G$. molle). Although others, such as $P$. lanceolata, were higher in the fall.

Similar to that described by previous authors (Curll and Wilkins 1985, Baker and Leaver 1986, Hunt 1989, Tallowin 1981, L' Huillier 1987, Xia et al. 1990), increasing stocking density resulted in increased tiller density.

Reductions in ADF values as stocking density increased in this study are similar to what has been found in other studies (Stockdale and King 1980, Freer 1960, Gordon 1973, Castle et al. 1968, Mayne et al. 1987, Kristensen 1988, Rugambwa et al.1990 ). This was a function of reduced flowering and lowering of the stem to green leaf ratio in the herbage (Munro and Walters 1985, Holmes 1989, Mott 1983).

Little dead material was accumulated in any season and treatment in this experiment due to the relatively high grazing intensity found at all stocking density treatments. This accounts for the similar ADF values for stocking density treatments.

Seasonal variation in ADF is dependent on the development state of pasture species. Generally, as plants mature ADF increases (Minson 1982, Demarquilly 1989, Holmes 1987, Munro and Walters 1985, Corral 1974, Valdés et al. 1991). This accounts for the higher ADF values after flowering.

Protein content found was within the typical range for temperate-type grassland vegetation (Demarquilly 1989). Crude protein levels increased as stocking densi-

Table 5. Acid detergent fiber (ADF), crude protein (CP), calcium (Ca), potassium (K) and magnesium (Mg) pasture content average and relationships $\mathrm{Ca} / \mathrm{P}(\%)$ and $\mathrm{K} /(\mathrm{Ca}+\mathrm{Mg})$ (miliequivalents/milliequivalents) of 3 years in each treatment and period (1:before flowering, 2:after flowering and 3:autumn) with their standard deviation.

\begin{tabular}{|c|c|c|c|c|c|c|c|c|}
\hline \multirow[t]{2}{*}{ Variable } & \multicolumn{3}{|c|}{ Treatment } & \multirow[t]{2}{*}{ Sig. } & \multicolumn{3}{|c|}{ Period } & \multirow[t]{2}{*}{ Sig. } \\
\hline & A & B & $\mathrm{C}$ & & 1 & 2 & 3 & \\
\hline & ------------------ & ---- & -------------- & & -----------------. & ----(\%)---- & -------------- & \\
\hline $\mathrm{ADF}$ & $26.26 \pm 3.84$ & $26.13 \pm 3.97$ & $25.64 \pm 4.59$ & ns & $23.05 \mathrm{~b} \pm 2.69$ & $28.28 \mathrm{a} \pm 4.09$ & $27.16 \mathrm{a} \pm 3.30$ & $* * *$ \\
\hline $\mathrm{CP}$ & $14.99 b \pm 3.82$ & $15.66 \mathrm{~b} \pm 4.03$ & $17.44 \mathrm{a} \pm 4.75$ & $* * *$ & $18.38 \mathrm{a} \pm 3.40$ & $14.47 b \pm 4.09$ & $17.89 a \pm 4.08$ & $* * *$ \\
\hline $\mathrm{P}$ & $0.32 b \pm 0.10$ & $0.32 b \pm 0.10$ & $0.35 \mathrm{a} \pm 0.10$ & $* * *$ & $0.44 \mathrm{a} \pm 0.09$ & $0.28 b \pm 0.08$ & $0.33 c \pm 0.06$ & $* * *$ \\
\hline $\mathrm{Ca}$ & $0.98 \mathrm{a} \pm 0.31$ & $0.92 b \pm 0.29$ & $0.96 \mathrm{ab} \pm 0.30$ & * & $0.90 \mathrm{a} \pm 0.32$ & $0.92 \mathrm{a} \pm 0.25$ & $1.06 b \pm 0.34$ & $* * *$ \\
\hline K & $2.23 b \pm 0.74$ & $2.31 b \pm 0.82$ & $2.51 \mathrm{a} \pm 0.81$ & $* * *$ & $2.79 \mathrm{a} \pm 0.75$ & $2.07 b \pm 0.77$ & $2.49 c \pm 0.76$ & $* * *$ \\
\hline $\mathrm{Mg}$ & $0.17 b \pm 0.05$ & $0.17 b \pm 0.04$ & $0.18 \mathrm{a} \pm 0.04$ & $* *$ & $0.17 b \pm 0.03$ & $0.18 \mathrm{a} \pm 0.04$ & $0.19 \mathrm{a} \pm 0.05$ & $* * *$ \\
\hline $\mathrm{Ca} / \mathrm{P}$ & $3.49 a \pm 1.65$ & $3.17 \mathrm{~b} \pm 1.51$ & $2.90 c \pm 2.96$ & $* * *$ & $2.16 \mathrm{a} \pm 0.88$ & $3.59 \mathrm{~b} \pm 1.51$ & $3.33 c \pm 1.26$ & $* * *$ \\
\hline $\mathrm{K} /(\mathrm{Ca}+\mathrm{Mg})$ & $0.98 \pm 0.47$ & $1.03 \pm 0.45$ & $1.08 \pm 0.47$ & ns & $1.33 \mathrm{a} \pm 0.55$ & $0.91 b \pm 0.38$ & $0.99 c \pm 0.39$ & $* * *$ \\
\hline
\end{tabular}

Sig: significance; ns:not significant; *:p<0.05; **:p<0.01; *** $\mathrm{p}<0.001$ 
5a)

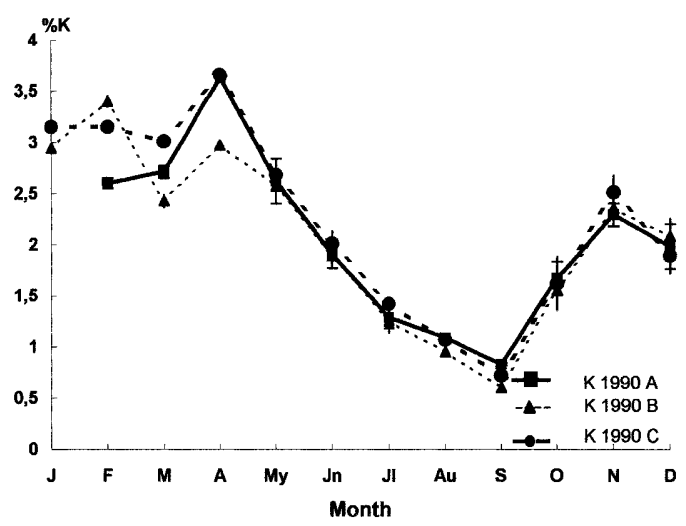

5b)

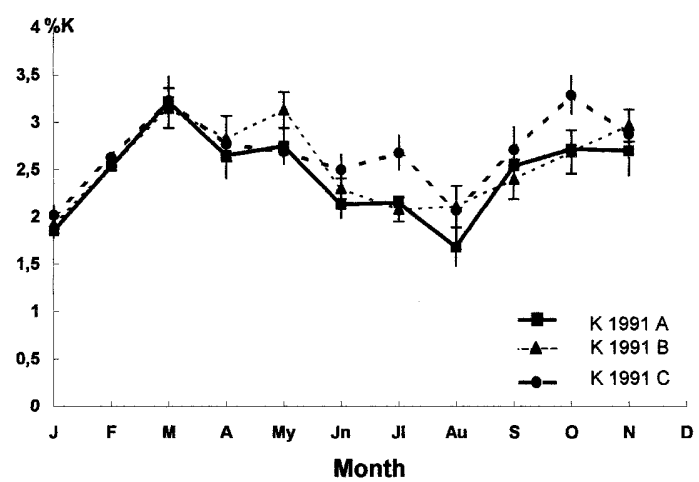

Fig. 5. Seasonal distribution of $K$ for the treatments $A, B$, and $C$, in 1990 and 1991.

ty increased. Short re-growth intervals and high grazing intensity, that is to say high stocking density, increase the protein content in the pastures, because flowering is reduced. This increases the leaf to stem ratio in herbage (Stockdale and King 1980, Overman and Wilkinson 1990, Castle et al. 1968). Since the protein content of leaves is greater than that in stem (Norton 1982, Demarquilly 1989), average protein content of the forage increases. However, the protein offered to cows did not differ among treatments, because Treatment A had higher amounts of forage on offer than Treatments B or C.

Crude protein levels were highest in spring and lowest in summer because post-flowering plants had less protein content than pre-flowering plants (Munro and Walters 1985, Metson and Saunders 1978b, Roberts 1987, Stehr and Kirchgessner 1976).

Herbage mineral content found was within the typical range for temperate type grassland vegetation (Grace 1983a, 1983b, 1983c, Pickard 1986), and mineral levels of grassland were always above the minimum limits recommended for dairy cows (NRC 1989, ARC 1991). Increasing stock- 6a)

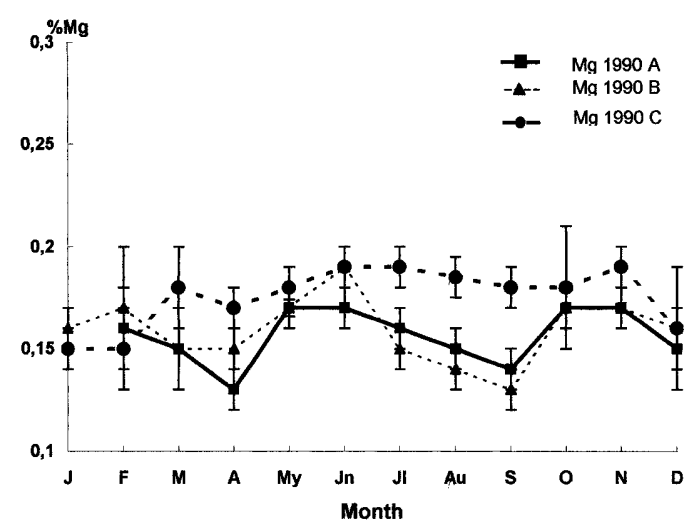

6b)

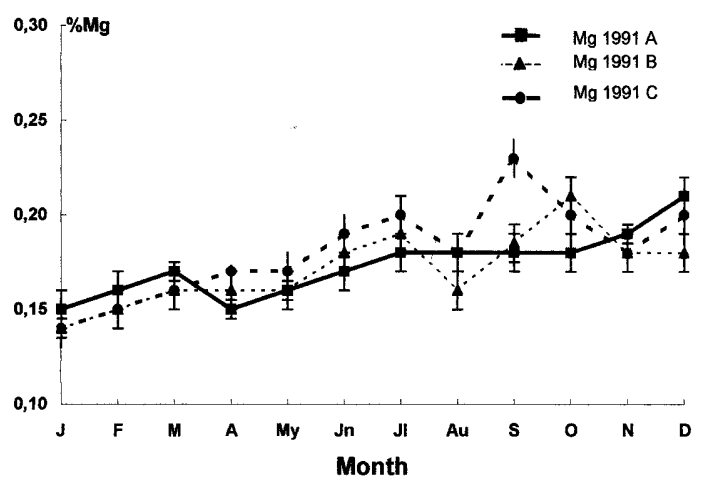

Fig. 6. Seasonal distribution of $\mathrm{Mg}$ for the treatments $\mathrm{A}, \mathrm{B}$, and $\mathrm{C}$, in 1990 and 1991. 7a)

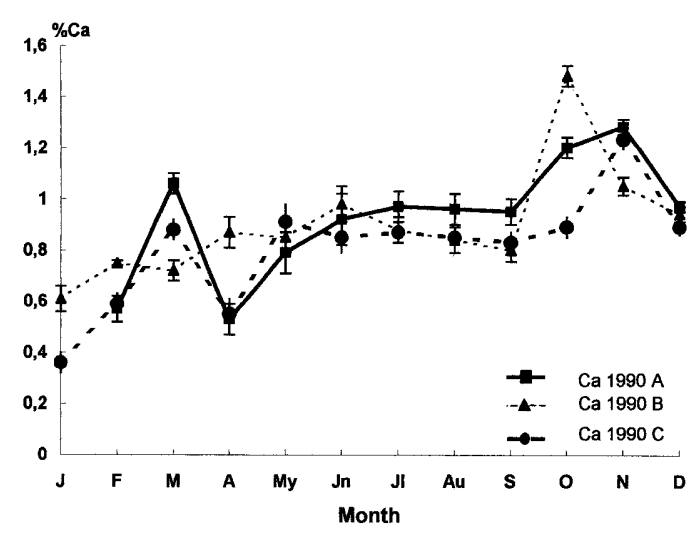

7b)

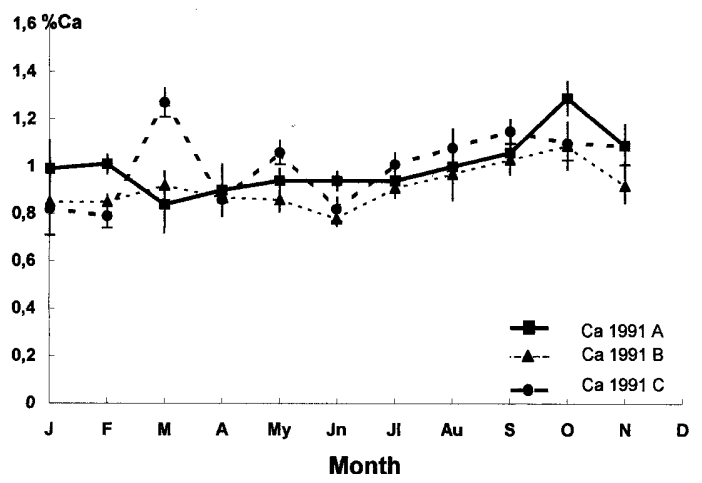

Fig. 7. Seasonal distribution of $\mathrm{Ca}$ for the treatments $A, B$, and $C$, in 1990 and 1991. 
8a)

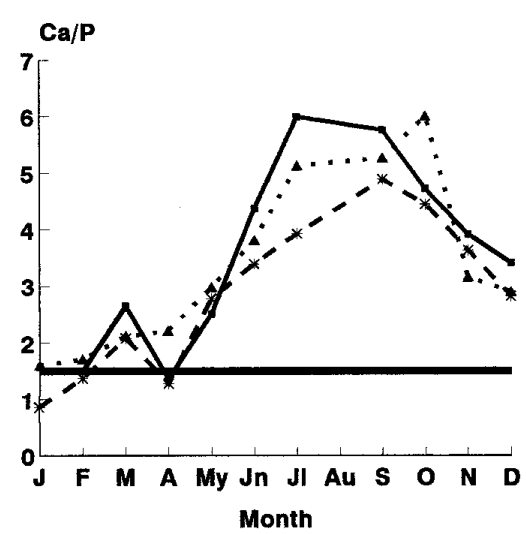

$8 b)$

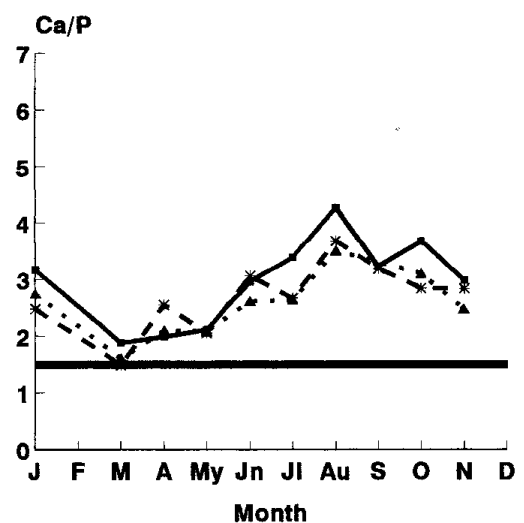

- Ca/P 1990 A

- Ca/P $1990 \mathrm{~B}$

*- Ca/P $1990 \mathrm{C}$ 9a)

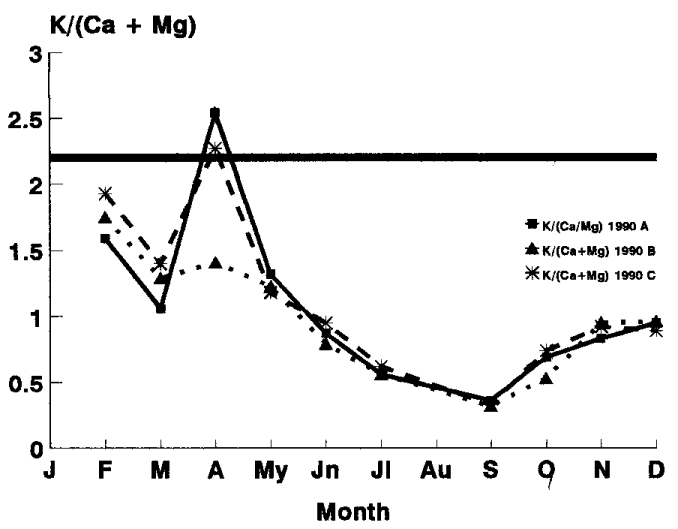

- Ca/P 1991 A

- Ca/P 1991 B

*- Ca/P 1991 C
$9 \mathrm{~b})$

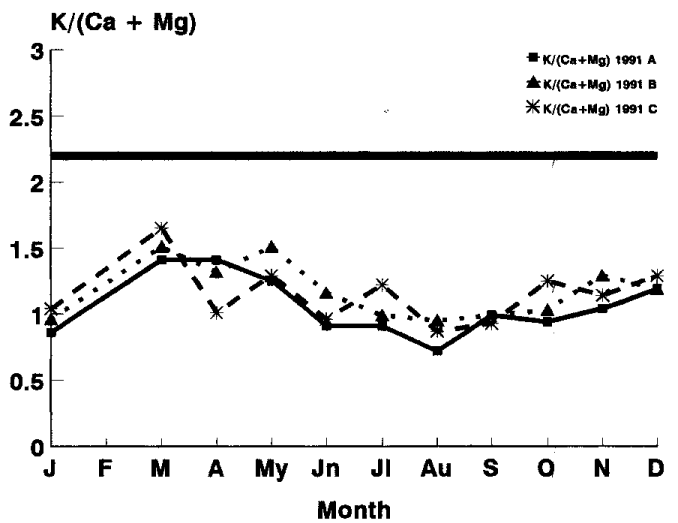

Fig. 8. Seasonal distribution of $\mathrm{Ca} / \mathrm{P}$ for the treatments $\mathrm{A}, \mathrm{B}$, and $\mathrm{C}$, in 1990 and 1991. Solid line indicates adequate value for animal intake described by Grunes and Allaway (1985).

ing density did increase the mineral content of pasture, because as for ADF and $\mathrm{CP}$, development stage and age of pasture species affects mineral content of the herbage. More intensive management as higher stocking rates also introduced more quantity of nitrogen and mineral elements (eg. potassium) in the soil mainly through faeces, which ususally increase soil contamination and recycling of nutrients. In the present experiment, $\mathrm{P}$ and $\mathrm{K}$ concentration decreased during the spring period as the plants approached flowering, as found by Andrieu et al. (1989), Norton (1982), Stockdale and King (1980) and Roberts (1987). In the summer P and K concentration were lower than in the other periods due to high temperatures and low rainfall which originated no leafy pasture and therefore an old pasture as found (Willman et al. 1994).
Magnesium and $\mathrm{Ca}$ varied little during the year as described by Roberts (1987), Metson and Saunders (1978a) and Golob and Cop (1990). Although, Mg and Ca levels were significantly lower in the spring than in the autumn.

Older recommendations indicate that the $\mathrm{Ca} / \mathrm{P}$ for grazing animals should be around 1.5 and within a range of 1-2 (Grunes and Allaway 1985, Gallego 1986). In the present experiment, the upper limit was exceeded throughout the year but no osteomalacia found (Grunes and Allaway 1985). The latest A.R.C. review ARC (1991) said that concerns with upper limits were incorrect, because ruminants tolerate a great variation of $\mathrm{Ca} / \mathrm{P}$ ratios.

The $\mathrm{K} /(\mathrm{Ca}+\mathrm{Mg})$ ratio is indicative of pasture tetany. If this ratio is higher than 2.2, problems of hypomagnesemia could appear (Kemp and T'Hart 1957, Butler
1963, Metson et al. 1966). In the present experiment, most of the time this relationship was not exceeded except in the spring of 1990, but no case of hypomagnesemia was found. This was probably because the animals were being fed concentrates $(2.5$ $\mathrm{kg} \mathrm{cow}$ day $^{-1}$ ) during the spring.

Previous small plot studies carried out in Galicia indicated that the $\mathrm{K} /(\mathrm{Ca}+\mathrm{Mg})$ ratio was always below 1.5 (Garcia et al. 1986) and that hypomagnesemia should not be a problem. Later surveys of dairy pastures showed that this recommended value could be exceeded during the spring, but that the feeding of concentrates rich in magnesium would be sufficient to correct the imbalance in the animals diet.

In our experiment (with medium level of soil fertility), stocking density had an important effect on tiller density but did not affect the botanical composition of the 
pastures. Higher stocking density increased the chemical quality of herbage. The $\mathrm{Ca} / \mathrm{P}$ relationship was not a good indicator of osteomalacia, because even when the recommended values were exceeded no problems occurred. It was possible to prevent hypomagnesemia problems by feeding $\mathrm{Mg}$ rich concentrates to the cows during the spring.

\section{Literature Cited}

Andrieu, J., C. Demarquilly, and D. Sauvante. 1989. Tables of feeds used in France, p. 459-485. In: R.Jarrige (ed.), Ruminant nutrition. Recommended allowances \& feed tables.

Agricultural Research Council (ARC). 1991. A reappraisal of the calcium and phosphorous requirements of sheep and cattle, p 573-612. In: A.F.R.C. Technical committee on responses to nutrients, Report 6. Nutrition Abstract and Reviews. Series B:Livestock feeds and feeding, 61(9), 573-612.

Baker, A. and J.D. Leaver. 1986. Effect of stocking rate in early season on dairy cow performance and sward characteristics. Grass and For. Sci. 41, 333-340.

Buttler, E.J. 1963. The mineral element content of spring pasture in relation to the occurrence of grass tetany and hypomagnesemia in dairy cows. J. Agr.. Sci., 60, 329-340.

Castle, M.E., I.N. Drysdale, and I.N. Watson. 1968. The effect of stocking rate and supplementary concentrate feeding on milk production. J. Britsh Grassl. Soc 23: 137-143.

Castro, P., A. González, and D. Prada. 1990. Determinación simultánea de nitrógeno y fósforo en muestras de pradera. XXX Reunión Científica de la Sociedad Española para el estudio de los pastos, 30: 200-207.

Corral, J. 1974. The effect of interruption of flower development on the yield and quality of perennial ryegrass, $\mathrm{p} 431-434$. Proc. V General Meeting Grassl. Fed.

Currl, M.L. and R.J. Wilkins. 1985. The effect of cutting for conservation on a grazed perennial ryegrass-white clover pasture. Grass and Forage Sci 40:19-30.

Demarquilly, C. 1989. The feeding value of forages p. 1817-1823. In: Proc. XVI Int. European Grassl.Congr. Nice, France.

Frame J. and I.V. Hunt. 1971. The effects of cutting and grazing systems on herbage production from grass swards. J. Brit. Agr. Soc. 26:163-171

Freer M. 1960. The utilization of irrigated pastures by dairy cows. II. The effect of stocking rate. J. Agr. Sci. 54:243-256.

Gallego J. 1986. Forma de cubrir las necesidades en materias minerales p. 115-142. In: MundiPrensa (Ed.) La alimentación del ganado.

Garcia P., F. Mombiela, and A. Mosquera 1986. Efectos del encalado sobre la composición química de praderas establecidas en terrenos a "monte". II. Magnesio, sodio, potasio, aluminio y cobre. Inv. Agr.. Producc y Sanidad Animales $1: 147-158$.

Garwood, E.A. 1969. Seasonal tiller populations of grass and grass/clover swards with and without irrigation. J. Brit. Grassl. Soc. 24: 333-344.

Goering, H.K. and P.J. Van Soest, 1970. Forage fiber analysis (apparatus, reagents, procedures and some applications). USDA Agr. Handb, 379

Golob A. and J. Cop. 1990. Seasonal variations in magnesium content of grasses p 204-205. Proc. VIII Gen. Meet. Eur. Grassl. Fed.

Gordon, F.J. 1973. The effect of high nitrogen levels and stocking rates on milk output from pasture. J. Brit. Grassl. Soc. 28:193-201.

Grace, N.D. 1983a. Calcium p. 100-105. In: Grace N.D. (Ed.) The mineral requirements of grazing ruminants.

Grace, N.D. 1983b. Magnesium. p. 92-99. In: Grace N.D. (Ed) The mineral requirements of grazing ruminants.

Grace, N.D. 1983c. Phosphorus. p. 106-112. In: Grace N.D. (Ed.) The mineral requirements of grazing ruminants.

Grunes, D.L. and W.H. Allaway. 1985. P 589-619. Nutritional quality of plants in relation to fertilizer use. In: Engelstad O.P. (Ed.) Fertilizer technology and use.

Holmes, C.W. 1987. Pastures for dairy cows. Occ. Pub. ${ }^{\circ} 10$ New Zealand. Soc. Anim. Prod. $\mathrm{p}$. 133-143.

Hume, D.E. and R.J. Lucas. 1987. Effects of winter cutting management on growth and tiller numbers of six grass species. N. Z. J. Exp. Agric. 15, 17-22.

Hunt, W. F. 1989. Grazing management effects on perennial ryegrass and white clover tiller populations pp 105-1056. XVI Int. Grassl. Congr.

Kemp, A. and M. t'Hart. 1957. Grass tetany in grazing milking cows. Neth. J. Agr. Sc. 5: 4-17.

Kristensen, E.S. 1988. Influence of defoliation regime on herbage production and characteristics of intake by dairy cows as affected by grazing intensity. Grass and For. Sci. 43: 239-251.

Little, T.M. and F.J. Hills 1987. Statistical methods in Agricultural Research. California E.U.A.

L'Huillier, 1987. Tiller appearance and death of Lolium perenne in mixed swards grazed by dairy cattle at two stocking rates. New Zeland. J. Agric. Res. 30:15-22.

Mayne, C., A.J. Clementes, and C. Huckle. 1987. Effect of buffer feeding grass silage on the grazing behaviour and animal performance of January/February calving cows p. 85-186. AFRC. VIII Silage Conf. Inst. for Grassl. and Anim.1 Prod.

Metson, A.J. and W.M.H. Saunders. 1987a Seasonal variations in chemical composition of pasture. I. Calcium, magnesium, potassium, sodium and phosphorus. New Zealnd. J. Agr. Res. 21: 341-353.

Metson, A.J. and W.M.H. Saunders. 1978b. Seasonal variations in chemical composition of pasture. II. Nitrogen, sulphur, and soluble carbohydrate. New Zealand J. Agr. Res. 21:355-364

Metson, A.J., Saunders, W.M.H., T.W. Collie, and V.W. Graham. 1966. Chemical composition of pastures in relation to grass tetany in beef breeding cows. New Zealand J. Agr. Res. 9: 410-436.

Minson, D.J. 1982. Effects of chemical and physical composition of herbage eaten upon intake. $p$ 167-182. In: Hacker J.B. (ed.), Nutritional Limits to Animal Production from pastures. Commonwealth Agr. Bur., Farnhan Royal, Great Britain.

Minson, D.J. 1990. Forage in ruminant nutrition. Academic Press Inc. Harcourt Brace Jovanovich Publishers. San Diego, Calif.

Mosquera-Losada, M.R. and A. GonzálezRodríguez. 1998. Effect of annual stocking rates in grass and maize+rye systems on pro- duction by dairy cows. Grass and For. Sci. 53:95-108.

Mosquera-Losada, M.R. and A. GonzálezRodríguez. 1999. Pasture production in Northern Spain dairy systems. N.Z. J. Agr. Res. 42:125-132.

Mott, G.O. 1983. Potential productivity of temperate and tropical grassland systems. XVI Int. Grassind Congress: 35-41.

Munro, J.M.M. and R.J.K. Walters. 1985. The feeding value of grass, p. 65-78. In: J. Frame (ed.) Proc. 19th Occ. Symp. Brit. Grassl. Soc. Suffolk., Great Britain.

Norton, B.W. 1982. Differences between species in forage quality, 91-109. In: Hacker J.B. (ed.), Nutritional Limits to animal Production from pastures. Commonwealth Agr. Bur., Farnhan Royal, Great Britain.

NRC, 1989. Nutrients requirements of dairy cattle Sixth Revised edition Update.

Overman, A.R. and S.R. Wilkinson. 1990. Estimation of nitrogen concentration in bermuda grass. Fertilizer Res. 21: 171-177.

Pickard, D.W. 1986. Minerals and vitamins. In: Broster W.H., Phipps R.H. and Johnson C.L. (Eds) Principles and practice of feeding dairy cows. Tech. Bull. 8, pp. 73-94.

Roberts, A.C.H. 1987. Seasonal variation in soil tests and nutrient content of pasture at two sites in Taranaki. New Zealand J. Exp. Agr., 15: 283-294.

Ruganbwa, V.K., Holmes C.W., A.C.P. Chu, and $H$. Varela-Alvarez. 1990. Milk production by cows grazing on Matua prairie grass (Bromus willdenowii Kunth) pastures maintained under different managements pp. 269-273. 50 Proc.New Zealand Soc. of Anim. Prod.

Stehr, W. and M. Kirchgessner. 1976. The relationship between the intake of herbage grazed by dairy cows and its digestibility. Anim. Feed Sc. and Tech. 1:53-60.

Stockdale, C.R. and K.R. King. 1980. The effects of stocking rate and nitrogen fertilizer on the productivity of irrigated perennial pasture grazed by dairy cows. I. Pasture production, utilization and composition. Aust. J. Exp. Agric. and Anim. Husbandry. 20:529-536.

Takasaki, Y., A. Isoda, H. Nojima, and H. Oizumi. 1989. Behaviours of annual and perennial grass species in the same genus, $p$. 449-450. XVI Int. Grassl. Congr. of European Grassl. Fed.

Tallowin, J.R.B. 1981. An interpretation of tiller number changes under grazing, p. 77-80. Occ. Symp. $\mathrm{n}^{\circ} 13$ of British Grassl. Soc.

Valdés, C., F.J., Giraldez, F.R. Bermúdez and F.J., Ovejero, 1991. Relaciones entre la composición química y la digestibilidad "in vivo" de hierba con distinto grado de madurez. IV Jornadas sobre Producción Animal de Información Técnica Económica Agraria 11: 214-216.

Willman, D., Acuña, G.H., Joy P. Michaud, 1994. Concentrations of $\mathrm{N}, \mathrm{P}, \mathrm{K}, \mathrm{Ca}, \mathrm{Mg}$ and $\mathrm{Na}$ in perennial ryegrass and white clover leaves of different ages. Grass and For. Sci. 49:422-428.

Xia, J.X., J. Hodgson, C. Mattew, and A.C.P. Chu., 1990. Tiller population and tissue turnover in a perennial ryegrass pasture under hard and lax spring and summer grazing, $p$. 119-122. LI Proc. New Zealand Grass1. Assoc. 